\title{
Återvunna symboler - den stora sovjetiska segern i en ny tid
}

\author{
Johanna Lärkner
}

\section{Linköping University Post Print}

N.B.: When citing this work, cite the original article.

Original Publication:

Johanna Lärkner, Återvunna symboler - den stora sovjetiska segern i en ny tid, 2006, Nordisk Østforum, 4, 405-424.

Copyright: Universitetsforlaget (Scandinavian University Press) http://www.universitetsforlaget.no/

Postprint available at: Linköping University Electronic Press http://urn.kb.se/resolve?urn=urn:nbn:se:liu:diva-40921 


\section{Återvunna symboler - den stora sovjetiska segern i en ny tid}

Den 9 maj 2005 firade Ryssland 60-årsjubileet av slutet på andra världskriget. I Moskva hölls en stor parad på Röda torget och president Putin hade bjudit in FN:s generalsekreterare och ett 50-tal stats- och regeringschefer från världen över. George W. Bush blev förste amerikanske president att bevittna en rysk militärparad. Paraden, som hölls klockan 10 på morgonen, direktsändes i rysk tv, och över hela landet hölls lokala firanden. Segerdagen, som den 9 maj kallas i Ryssland, är en av landets största högtider, och firades med extra pompa och ståt jubileumsåret 2005. Den är en av få, förmodligen den enda sovjetiska högtid med ideologiska övertoner som firades likadant då som nu.

Denna artikel handlar om firandet av segerdagen och 60-årsjubileet av krigsslutet så som det utspelade sig i landets andra stad S:t Petersburg. Leningrad som staden hette på den tiden var utsatt för en lång tysk belägring och är en av de så kallade hjältestäderna från andra världskriget (eller stora fosterländska kriget 1941-45 som det oftast benämns i Ryssland). Huvudintresset för undersökningen är hur bilden av andra världskriget och den sovjetiska segern ser ut i dagens offentlighet, samt hur Sovjetunionen och sovjetiska symboler omtolkas i firandet av segerdagen.

Artikeln bygger på fältarbete i S:t Petersburg våren 2005, samt studier av två ryska nyhetstidningar under samma tidsperiod. Tidningarna är tabloiden Komsomolskaja pravda och veckotidningen Argumenty i fakty, två av Rysslands största nyhetstidningar, som båda har rikstäckande såväl som lokalt material. Båda är populära tidningar med en "folklig" framtoning, men skiljer sig åt i det att Komsomolskaja pravda har kvällspressens alla kännetecken medan Argumenty i fakty har en mer seriös framtoning med längre och djupare artiklar. ${ }^{1}$

\footnotetext{
${ }^{1}$ Under tidsperioden januari till maj 2005 publicerade Argumenty i fakty 50 artiklar med anknytning till andra världskriget och segerdagen. För Komsomolskaja pravda är samma siffra 105. Medräknat är artiklar både i det rikstäckande materialet och i lokalmaterial från S:t Petersburg.
} 


\section{Segerdagens historia}

Efter fyra års krig med Sovjetunionen kapitulerade Tyskland den 8 maj 1945 villkorslöst. Det stora fosterländska kriget beräknas då ha krävt runt 25 miljoner sovjetiska liv (Harrison 2003). Till följd av tidsskillnaden mellan Berlin och Moskva hade det vid tidpunkten för kapitulationen hunnit bli den 9 maj i Sovjetunionen och därav är det denna dag som firas som segerdagen. Enligt historikern Nina Tumarkin som skriver om kulten av stora fosterländska kriget i Sovjetunionen, började sakraliseringen av kriget medan det ännu pågick. Den första segerparaden hölls den 24 juni 1945 på Röda torget, och 1946 var segerdagen en helgdag som firades stort. Men redan året efter var segerdagen en vanlig arbetsdag då Stalin var angelägen om att skapa distans till kriget och nedtona krigshjältarnas betydelse.

Från 1947 till 1965 var firandet främst informellt, där veteraner träffades, man besökte kyrkogårdar och promenerade (Tumarkin 1994: 104). Det var under Brezjnevåren (1964-82) som kulten av kriget kom igång på allvar. Segerdagen blev åter en allmän helgdag 1965. Historikern Amir Weiner skriver att tjugoårsjubileet av segern 1965 markerade en övergång från ett levande till ett historiskt minne av kriget och ett medvetet försök att utveckla en minneskanon och en känsla av avslut - och en integrering av kriget i vad han kallar "the Bolshevik master narrative" (Weiner 2001: $233,317)$.

Från 1965 och två decennier framåt hade kulten sin höjdpunkt. Under Gorbatjovåren skedde en viss omvärdering av kriget. I sitt tal vid 40-årsjubileet lade Gorbatjov vikt vid de tragiska aspekterna, lyfte fram vanliga medborgare istället för partiet, tackade de västerländska allierade först istället för sist vilket varit brukligt, och uppehöll sig vid de kolossala förlusterna (Tumarkin 1994: 184). Mot slutet av 1980-talet hade en svängning skett, och veteraner valde att inte bära sina medaljer offentligt för att undvika kritik eller göras till åtlöje. Tumarkin beskriver firandet år 1990 som kultens svanesång, påverkad av socialismens kollaps runt omkring hade man tonat ner segeraspekterna, och fokuserade mer på att hedra de döda (ibid.: 200).

Tumarkin menar att kulten av det stora fosterländska kriget var tvådelad: den innehöll både minne och propaganda, den var både "genuin” och “skapad”. De stora känslor som fanns förknippade med minnet av kriget gjorde det tacksamt att använda för 
andra syften. En äldre kvinna uttalade till exempel i samband med 40-årsjubileet att hon visste att regimen utnyttjade minnet av kriget för sina egna syften, men samtidigt var minnet av kriget heligt för hennes generation (Tumarkin 1994: 147).

Kriget började alltså omvärderas när Sovjetunionen knakade i fogarna. De första åren efter Sovjetunionens fall ställde man in paraderna och firandet av segerdagen minskade i omfattning. Anna Krylova (2004a) menar att veteranerna inför firandet 1992, vilket var det första efter Sovjetunionens fall, hånades och framställdes som stofiler vilse i den nya tiden och som den gamla regimens hantlangare. Deras dekorationer kallades för leksaker och de liknades vid julgranar. Enligt Krylova förekom också fysiska attacker, och veteraner beskylldes av unga människor för att vara förslavare snarare än befriare.

Inför segerdagen 1992 hängde varken stadsstyret eller den federala regeringen upp en enda röd flagga i Moskva. Segerparader på Röda torget och i andra större städer, vilka varit en del av firandet sedan mitten på 1960-talet, ställdes in på presidentens order. I processen att omvärdera sovjettiden var segern 1945 inte längre den källa till självkänsla och stolthet den fungerat som under nästan ett halvt sekel, istället framställdes den allt oftare i negativt ljus (Krylova 2004a: 85-87). Men även 1992 fanns det de som ville fira segerdagen. Tusentals veteraner kom från hela Ryssland till Moskva, precis som på sovjettiden. Med flaggor och banér färgade de under flera timmar centrala Moskva rött. Uppklädda i medaljprydda uniformer samlades de på gator och torg för att försvara sin version av kriget och historien (ibid.: 89).

Krylova menar att redan 1993 började åter viss sympati visas veteranerna, och yngre människor deltog i marscherna för att ge veteranerna och/eller deras bild av historien sitt stöd. Kommunistpartiet hade hela tiden framställt sig som de som stod på veteranernas sida, men fram mot mitten av 1990-talet började även Jeltsinsidan utnyttja segern för egna politiska syften. De framställde nu segern som ett hjältedåd som folket inte fått njuta frukterna från eftersom den stulits från folket av det sovjetiska systemet. Man ersatte det sovjetiska med rysk patriotism, och försökte etablera kontinuitet till det ryska imperiet. Krylova skriver att vid 50-årsjubileet 1995 var det som om två olika högtider firades. Det ena, det officiella firandet, visade på 
denna "ryska" version av segern. Det andra framhöll de röda fanorna och det sovjetiska i segern (Krylova 2004a: 99).

\section{Segerdagen i S:t Petersburg 2005}

Firande av 60-årsjubileet i S:t Petersburg hade flera delar. I anslutning till jubileet invigdes ett flertal nya monument och minnesmärken, och äldre sådana högtidlighölls med blomsternedläggningar. På förmiddagen den 9 maj hölls ett slutet firande på Slottsplatsen - en militärparad med 25 bataljoner från regionen och fyra tusen militärtjänstgörande. På eftermiddagen hölls som varje år ett segertåg med veteraner på stadens huvudgata Nevskij prospekt, som var kantad av åskådare. Utmed gatan stod det folk i fönster, på balkonger och till och med på taken. När tåget passerat förbi, började åskådarna fylla Nevskij prospekt och gå i riktning mot Slottsplatsen. Människor i fönster hurrade och jublade och möttes av hurrarop och jubel tillbaka. Några i denna spontana parad stämde upp i segersånger. Från en balkong framfördes marschmusik. På bron över Fontankan kunde man se hur Nevskij prospekt var svart av människor både bakåt och framåt. På Slottsplatsen, framför Vinterpalatset, hölls sedan konsert och tal och det släpptes upp röda ballonger och vita duvor i skyn. På kvällen sköts fyrverkerier från Peter-Paulsfästningen.

Firandet av segerdagen, framhållandet av stora fosterländska kriget och belägringen av Leningrad samt framhävandet av veteranerna genomsyrade offentligheten i S:t Petersburg våren 2005. Det var inte bara under själva dagen som man märkte av segerdagen, affischer och dekorationer började sättas upp flera månader i förväg och satt kvar långt efteråt. Museerna hade speciella minnesutställningar, tidningarna skrev om kriget och segern och gamla sovjetiska krigsfilmer repriserades. Tv-nyheterna hade så gott som dagligen inslag om kriget. Det började dyka upp Stalinbiografier av ett mer förhärligande slag, och det var röda fanor och stjärnor på många håll. I princip alla affärer hade segerdagsdekorationer.

Det var ett firande på många olika nivåer, det firades i stadsrummet, i medieoffentligheten, men det var också en dag som firades även privat. Segerdagen, framhöll många, var viktig för att den inte var förknippad med någon speciell kultur och religion. Den var gemensam för alla Sovjetunionens folk. Firandet av segerdagen 
var något som tydligt relaterades till en ryssländsk ${ }^{2}$ identitet. Men det fanns även en tydligt lokal aspekt, då Leningrads status som hjältestad och den långa belägringens ohyggliga förhållanden lyftes fram. Slutligen hade firandet också ett tydligt politiskt innehåll och utformning, som syftade mot goodwill och identitetsskapande.

\section{Myter och symboler}

I segerdagsfirandet 2005 förekom många symboler som hämtats från sovjettiden. På affischer och plakat fanns röda stjärnor och hammaren och skäran, och i segertåget och utmed stadens gator vajade röda fanor. I en post-sovjetisk kontext har emellertid inte sådana symboler exakt samma betydelse som de hade förut. Betydelsen förskjuts, symbolerna har med sig sin gamla betydelse, men nya betydelser kommer som nya lager ovanpå.

Resonemanget baseras på den lingvistiska teckentolkningsmodellen där varje tecken består av två delar; det betecknande som är beskrivande (t.ex. ordet regn) och det betecknade som är betydelsebärande (t.ex. fenomenet regn). För att kunna förklara hur mening i symboler förskjuts kan man ta den ryska matrosjkadockan som en modell. Varje docka kan delas på mitten, underdelen får stå för det betecknande, och överdelen för det betecknade. Genom att sätta ihop delarna får vi ett tecken. Genom att ställa den färdiga dockan i underdelen på nästa docka får vi ett nytt betecknande, som kan kombineras till ett nytt tecken. I detta nya, identiska tecken finns den gamla bilden med. Den inre dockan syns inte, men den märks genom sin tyngd och att det skramlar när man rör dockan. Proceduren kan sedan upprepas. För varje gång får vi ett nytt tecken som är identiskt men ändå inte, som har den gamla betydelsen skramlandes inuti sig men som också betyder något annat. I den nya betydelsen finns den gamla kvar, men den är en mindre del.

Figur 1. Modell över symbolers betydelseförskjutning

\footnotetext{
${ }^{2}$ På ryska skiljer man mellan ryskt (russkij) som är en etnisk beteckning och ryssländskt (rossijskij) som syftar på medborgarskap och bildas av landets namn Rossija, alltså samma skillnad som på svenska görs mellan finsk och finländsk. För att få fram denna skillnad kommer jag att använda orden ryssländsk och ryssländare.
} 
Denna modell är baserad på Roland Barthes Mytologier (1970). Han ser myten som en del av den Saussurebaserade teckentolkningsläran. Barthes definition av myt är att den “är ett yttrande”. Definitionen är bred: "Eftersom myten är ett yttrande, kan allt som hör till talet vara en myt" (Barthes 1970: 205). Han framhåller att myten är ett kommunikationssystem, ett sätt att ge betydelse åt något. Myten bildas dock inte av intet, den härrör från något, utgår från ett redan utarbetat material (ibid.: 206). Barthes skriver att "myten är både ett stulet och återlämnat yttrande. Men det yttrande som man för med sig är inte längre helt och hållet det som man stulit: När man lämnar tillbaka det, placerar man det inte åter exakt på dess tidigare plats” (ibid.: 223). Myten slipar bort detaljer, den skapar ofullständiga bilder och meningen rensas bort. Den fyller yttrandet med en egen betydelse. Barthes betonar det entydiga och ickeresonerande hos myten men också det svårfångade hos dess ständigt föränderliga betydelse. Barthes menar vidare att moderna myter, särskilt det han kallar högermyterna, naturaliserar historien. De är konservativa och har en naturaliserande och döljande effekt.

Firandet av segerdagen har många rituella drag: Det är i stora delar formaliserat och utlyft ur vardagen. Firandet saknar förvisso en explicit religiös koppling, men begreppet ritual har tillämpats utanför en religiös kontext. I Secular Ritual (1977) definierar Sally F. Moore och Barbara G. Myerhoff några av ritualers egenskaper. De menar att utmärkande för ritualer är upprepning och förutsägbarhet. Vidare betonas att ritualer är avskiljda från vardagslivet och är ägnade att framkalla ett visst stämningsläge samt att de har en kollektiv dimension, eller en social mening (Moore \& Myerhoff 1977: 7-8). Det som framförallt är intressant här, är den grad till vilken rituellt beteende är formaliserat. Det anknyter till Barthes beskrivning av myt ovan. Ritualer ger en ram inom vilken allt ska passas in. Det finns utrymme för spontanitet, men inom givna ramar.

En viktig aspekt i firandet är vad Victor Turner kallar “communitas” (Turner 1995: 132-40). Communitas är en känsla av gemenskap och djup samhörighet som kan uppstå i ritualer. Kännetecknande är likhet och delade upplevelser som står i konstrast till vardagslivets åtskillnad. Det är enighet bortom hierarki. En sådan communitas kan till exempel sägas ha uppstått bland åskådarna till segertåget: Sinnesstämningen var uppsluppen, folk stämde upp sånger där okända föll in, folk pratade med varandra, 
fällde kommentarer till främlingar, hade ballonger och viftade med flaggor. Känslan av gemenskap var påtaglig, det var svårt att vara oberörd.

Förhållandet till historien, och olika tolkningar av det förflutna, är också en viktig ingrediens i segerdagsfirandet. Historien är inte bara en produkt av det förflutna, utan också av samtidens önskningar och behov. Det har skett ett oändligt antal händelser i det förflutna. Bara ett fåtal anses förtjäna en plats i historieböckerna, och dessa tolkas in i en världsbild som motsvarar historieskrivarens (Eriksen 1996: 14). Det finns alltså inte en historia, det finns många. I Det vilda tänkandet skriver Claude Lévi-Strauss att historien är oundvikligt partisk och partiell, vilket i sig är en form av partiskhet. Urvalet är nödvändigt, menar Lévi-Strauss, eftersom en verkligt total historia skulle innebära kaos, men det innebär också att varje historiskt faktum är konstruerat eftersom det är skapat utifrån ett urval av en "mångfald av psykiska och individuella rörelser" (Lévi-Strauss 1987: 256). Lévi-Strauss visar på att de europeiska historierna på centrala punkter är samstämmiga med skriftlösa folks myter. De har ett normativt och kulturellt fäste i nutiden och återger det förflutna från nutidens horisont. ${ }^{3}$ Så vad har de historiska myterna för funktion? Förutom att ge självkänsla bringar de ordning i kaos, ger världen en moralisk struktur och redogör för distinktionernas upprinnelse. Myterna är nödvändiga för att världen ska framstå som meningsfull (Eriksen 1996: $22,115)$.

Detta för oss över till begreppet "mytisk tid". Eriksen exemplifierar mytisk tid med afrikanska förfäder som till skillnad från levande människor inte blir äldre - de är fastfrusna utanför tiden (Eriksen 1996: 47). Genom ritualer kan man närma sig den mytiska tiden, de skapar "moment in and out of time" som Turner uttrycker det (Turner 1995: 96). Trots att de veteraner som intervjuas i mitt material är verkliga människor av kött och blod kan man se en sådan aspekt i stora fosterländska kriget. Det blir ett händelseförlopp som lever parallellt med nutiden. Veteranerna återutför sina hjältedåd från 60 år sedan, evigt unga och kraftfulla.

\footnotetext{
${ }^{3}$ Ett liknande synsätt förs fram av Bruce Kapferer (1988) som i en jämförelse av nationalism på Sri Lanka och i Australien likställer singalesiska buddhistiska myter och australiska myter om första världskriget.
} 
Krig är dessutom ofta centrala i nationalistiska myter. Kapferer skriver att "war tests for national quality. It can reveal the artifice and falsity of national presentation as it can expose, negatively or positively, the 'true' person beneath the routine social mask" (Kapferer 1988: 187). Att dö för sitt land förutsätter en "moral grandeur” som det att ge sitt liv för något som man kan gå med i eller lämna efter egen vilja inte motsvarar (Anderson 1991: 144). Moral grandeur står centralt i berättelserna om kriget. Det är det som i tidningsartiklarna lyser om veteranerna, som visserligen överlevde men var beredda att ge sitt liv för fosterlandet. ${ }^{4}$ Kriget visade på de nationella kvaliteterna, det visade ett folk som växte med uppgiften och framställer nu en generation i ett annat moraliskt ljus.

\section{I det offentliga rummet}

Den 9 maj togs centrala S:t Petersburg i princip helt över av segerdagsfirandet. Nevskij prospekt stängdes på eftermiddagen av för veteranernas segertåg. Det var förmodligen inte möjligt att vistas i S:t Petersburg utan att märka att något var på gång. Det kändes i luften att det inte var en vanlig dag. Förmiddagens parad var visserligen bara för särskilt inbjudna, men under eftermiddagen och kvällens öppna aktiviteter, med tåg, konserter och fyrverkerier, var centrum så fullt med folk att det var svårt att ta sig fram.

Som nämnts ovan var det inte bara under själva dagen som man märkte av jubileet. Redan från slutet av mars satte stadens myndigheter upp affischer om segerdagen. Dessa hängde som banderoller ovanför gatorna, plakat på offentliga platser och affischer på reguljära reklampelare. Över hela staden kunde man se bilder av de hjälteofficerare som ledde röda armén under kriget eller av anonyma soldater. Det fanns återanvända planscher från krigsåren, eller också någon mer symbolisk dekoration. Segerdagstemat användes även som inramning till annat, till exempel som dekoration på reklamaffischer, och många affärer erbjöd speciella rabatter till veteraner. Ju närmre dagen man kom desto mer affischer kom fram. Skyltfönster fylldes av segerdagsdekorationer, affärer satte upp affischer och det såldes

\footnotetext{
${ }^{4}$ Det finns även andra ideologiska övertoner än de nationella. Det var inte bara för fosterlandet, utan också för kommunismen man kämpade. Det framhålls också ofta att de sovjetiska soldaterna gav sina liv för ett Europa fritt från nazism.
} 
segerdagskort (postkort), kalendrar (maj 2005 till maj 2006), och massor av böcker. Min personliga favorit var flygbolaget Pulkovos speciella segerdagsvåtservett.

Affischerna representerade en tillfällig omformning av stadsrummet. De urskiljde stadsrummet från vardagen och signalerade att något var på gång. David Crowley och Susan E. Reid (2002) har visat hur man under kommunisttiden försökte omforma den förra erans storslagna platser och ge dem en ny mening. Det var till exempel ingen tillfällighet att alla förstamajtåg i S:t Petersburg mynnade ut på Slottsplatsen. Genom att använda dessa platser i ett nytt sammanhang kunde man ta över dem utan att bygga om. Slottsplatsen var också ett centrum för firandet av segerdagen. Det var här paraden på förmiddagen skedde, här mynnade veteraners segertåg ut och här stod en stor scen från vilken det hölls tal, sjöngs sånger och spelades musik. På byggnaden som flankerar Vinterpalatset hade man hängt upp en enorm banderoll med stora fosterländska krigets orden som består av en röd stjärna med hammaren och skäran i mitten.

Just korten och affischerna är ett av de tydligaste exemplen på vilken symbolik som användes i firandet. Dekorationerna ger en tydlig association till Sovjetunionen. I utsmyckningarna ingick ett fåtal fotografier (oftast den närmast ikoniska bilden med den sovjetiska flaggan på riksdagshuset i Berlin). I stället förekom ofta tecknade bilder. Dessa föreställde ibland människor men oftare olika stiliserade uttryck för kriget (t.ex. kartor, emblem och ordnar). Röda fanor, bilder av veteraner eller från kriget och blommor är andra vanliga motiv. Ofta kombinerades flera motiv. Dessa symboler bestod nu likt matrosjkadockor av flera lager med mening. Sovjetunionen framställdes i segerdagsfirandet främst som det förlorade fosterlandet, en bild av den gamla goda tiden då man bodde i ett land som var en världsmakt. Det var bilder av forn storhet och historiska hjältedåd. Ett relativt litet antal motiv utgjorde majoriteten av dekorationerna. Inga påminde egentligen om krigets smutsigare sidor, utan de var "rena" symboler för segern.

Tillsammans med denna tillfälliga omformning av stadsrummet fanns en mer permanent, den som genom monument och minnesmärken ska vara en konstant påminnelse om kriget och segern. Thomas Borén (2005) skriver i sin avhandling om Petersburgförorten Ligovo, vars nuvarande bebyggelse främst är höghus byggda på 
1970-talet, att områdets historia uttrycks i monument från stora fosterländska kriget. Frontlinjen gick genom Ligovo vilket nu markeras av en björkallé. Han menar att stora fosterländska kriget inte bara betraktades som ett lands seger över ett annat, utan också som en seger för socialismen:

As the war had concerned all Soviet citizens (...), their symbolic power was used by the central authorities as a uniting historical factor in forming a supposedly Soviet identity. The monuments and names are part of this and they are thus not only memorials to the horrifying human losses of the war (...) but also the Soviet authorities' ideological stamp on urban space (Borén 2005: 90).

Borén menar att dessa monument och andra offentliga utsmyckningar säger något om vad det innebar att vara en sovjetmedborgare i Leningrad, eller åtminstone om hur myndigheterna ville att sovjetisk identitet skulle se ut. Att resa monument och att namnge områden och gator var ett sätt att skriva in "the Soviet master narrative in local space" (Borén 2005: 107). Genom monument och historiska platser vävdes historien och nutiden samman.

I centrala S:t Petersburg finns två minnesmärken som i sig är anspråkslösa, men som är betydelsefulla som markörer av umbärandena under belägringen och vid vilka folk lägger blommor. Det ena är på Isakskatedralen, en av S:t Petersburgs mest berömda byggnader, där man låtit några hål från granatbeskjutningen under belägringen vara kvar och försett dem med en minnesplakett. Det andra finns nära palatsänden av Nevskij prospekt, och är en skylt från belägringen. Den är målad direkt på väggen med vita bokstäver på en blå bakgrund och texten lyder: "Medborgare! På den här sidan gatan är det farligast att vistas vid granatbeskjutning.” Denna skylt var en viktig anhalt för många under segerdagen, och man kunde till slut knappt se texten för alla blommor.

De permanenta minnesmärkena skiljer sig från den tillfälliga omformningen av stadsrummet. Dels innebär just det faktum att de är permanenta att människor har hunnit skapa en relation till dem. De ingår i segerfirandet, och dekoreras av tillfälliga symboler. Medan de tillfälliga dekorationerna är väldigt fokuserade på seger och 
triumf, minner många av minnesmärkena om krigets och belägringens umbäranden och lidande. Lidandet är en del av bilden av kriget, men med segern är lidandet besegrat. Uppsättandet av affischer och banderoller kommer uppifrån (stadsstyret), högtidlighållandet av minnesmärken är till stor del folkligt, något som kommer nedifrån. Det finns dock egentligen ingen motsättning mellan dessa två nivåer, de betonar endast olika aspekter som samverkar till en gemensam bild.

\section{Veteranernas berättelser}

Den mest framträdande delen av tidningarnas rapportering kring kriget och segerdagen är veteranernas berättelser. Dessa är både från fronten och från liv i ockuperat och krigshärjat land, från dem som tjänstgjorde i stridande förband eller hade andra uppgifter som sjukvårdare eller brevbärare och från dem som blev kvar hemma. Det är både intervjuer med veteraner och utdrag ur brev eller dagböcker. Största delen av dem som intervjuas i tidningarna var barn eller unga under kriget. Detta förklaras säkerligen av den tid som förflutit sedan kriget och att de som var äldre då inte längre finns vid liv. Men det ger en förskjutning av perspektiv och mycket uppmärksamhet riktas mot hemmafronten, främst belägringens Leningrad. Det är barnen som tvingades bli vuxna i förtid och utföra uppgifter åt armé och partisanförband, och de som gick direkt från skolan in i armén som är de vars historier förs fram. Detta sagt, så är redogörelser av livet vid fronten flitigt förekommande i artiklarna. Både i form av utdrag ur brev skrivna under kriget och veteraner som i nutiden berättar sina minnen.

Komsomolskaja pravda inleder sin artikelserie "Den stora segerns hemligheter" den 2 februari med en halv sida av tidningens chefredaktör om vikten av att minnas. Denna första artikel handlar sedan om fyra, numera döda, personer som artikelförfattaren tidigare intervjuat. En av dessa är den legendariske marskalk Georgij Zjukov (18961974) som förärades utmärkelsen Sovjetunionens hjälte inte mindre än fyra gånger. Journalisten berättar hur han för många år sedan träffade Zjukov för en intervju. Zjukovs roll som legendar är tydlig och läsaren förväntas känna till vad han gjorde under kriget. Artikeln avslutas med några ord av Zjukov:

När vi firar segern, kommer vi alltid minnas, vilka av vårt folks egenskaper som hjälpte till att besegra fienden. Tålamod, mod, storslagen uthållighet. 
Fosterlandskärlek. Låt dessa egenskaper som i krigselden visat sitt värde fortsätta vara våra följeslagare. Då kommer segern alltid att vara med oss (Peskov 2005).

De flesta veteraner som sedan intervjuas är som regel betydligt mindre kända än Zjukov, det är i stor utsträckning "vanliga människor" (om än med många medaljer) som berättar om sina krigsupplevelser. Men Zjukovs slutord kan sägas vara ett ledord för hur tidningarna skriver om veteranerna. Det är de egenskaper han nämner som lyfts fram. Det är den ideologi som dessa ord innehåller som journalisterna förmedlar med sina artiklar. Fosterlandskärlek är ett återkommande tema i berättelserna.

Jennifer Dickinson (1995) intervjuade veteraner i S:t Petersburg alldeles efter Sovjetunionens fall. Hon fann att många kände sig vilsna i den nya tiden. Förr var de respekterade som bärare av en levd historisk sanning, nu fann många att deras historier ignorerades eller i värsta fall betraktades som den gamla regimens lögner. Ögonvittnesskildringar hade en viktig roll i den sovjetiska historieförmedlingen om kriget. Veteraner besökte klassrum, intervjuades i tidningar, var med i böcker och liknande. Då Sovjetunionen föll splittrades den förut enade rösten om unionens historia. Då så mycket annat från den tiden visat sig vara lögn, frågade sig många varför det skulle finnas sanning i veteranernas berättelser. Många unga avfärdade sovjetiska erfarenheter som irrelevanta i ett post-sovjetiskt liv. I stället var de ivriga att föra fram nya sanningar som avtäckte bedrägeriet i den sovjetiska historien.

Dickinson menar att vittnesberättelserna från belägringen visar hur historiska fakta är kulturellt konstruerade och föränderliga. Efter Sovjetunionens fall ändrade veteraner sina berättelser för att göra dem relevanta i en ny kontext. Problemet veteranerna ställdes inför var att ta en narrativ form som var central i den sovjetiska historieskrivningen om kriget och genom den bekräfta många av den sovjetiska historiens sanningar om kriget. Samtidigt gällde det att framställa sig med distans till “den gamla regimens lögner”. Dickinson menar att man hade två huvudtaktiker för att komma runt detta dilemma. Den ena var att diskutera ämnen som förut var tabu. Den andra var att kontextualisera och rättfärdiga befolkningens nästan mytiska patriotiska svar på kriget genom att betona de stora skillnaderna mellan Sovjetunionen på 1930- 
och 1940-talen och det sena sovjetiska och tidiga post-sovjetiska samhället (Dickinson 1995).

Tidigare tabun som kannibalism och bedrägerier är vanliga inslag i de berättelser från belägringen som nu publiceras, och ofta påpekas också att det här är tidigare tabuämnen. Även om situationen för veteranerna nu är annorlunda än vad den var under tidigt 1990-tal, kan man se ett behov att markera viss distans till den sovjetiska historieskrivningen. Till exempel betonas det att breven man publicerar censurerades under kriget, eller att man har fått material ur tidigare stängda arkiv. Berättelserna från belägringen är berättelser om ett ofattbart lidande, och om invånarnas uppoffringar. Samtidigt är det som berättas i artiklarna förmodligen inget nytt för tidningens läsare. S:t Petersburgs invånare är väl medvetna om belägringens hemskheter, men det verkar finnas ett behov av att berätta om och om igen. ${ }^{5}$

Det finns också exempel på sådant i tidningarnas skildringar av kriget som tar direkt avstånd från tidigare historieskrivning. Under kriget stämplades hela folkgrupper som landsförrädare och deporterades av Stalin. Ett sådant exempel är ingusjierna, en folkgrupp i norra Kaukasus. Under kriget deporterades hela folket till Centralasien, men tilläts återvända på 1950-talet. Den 16 mars 2005 hade Argumenty i fakti en artikel om ingusjiska soldater som kämpade på Leningradfronten. Artikeln inleder med att skriva att det till den 9 maj kommer att resas en ny minnestavla på Piskarevskijkyrkogården till minne av de ingusjier som slogs för stadens försvar. Artikeln återberättar ödet från några av de ingusjiska soldater som kämpade på Leningradfronten och konstaterar att företrädare för alla Sovjetunionens folk deltog i försvaret av Leningrad. Man avslutar med att säga: "Krig och död känner ingen nationalitet, men minnet måste veta" (Krikunov 2005).

\footnotetext{
${ }^{5}$ Nancy Ries (1997) framhåller att lidandet är ett nyckelelement i de konversationer från perestrojkatiden som hon analyserar. Hon menar att lidande och förmågan att uttrycka sin utsatthet är något som värderas i Ryssland. Litanior är en central ingrediens i samtal och berättelser. I de litanior som Ries diskuterar är huvudpersonerna oftast kvinnor, barn eller gamla. Även i berättelserna från belägringen står dessa grupper i fokus. Det är kvinnor och barn som är belägringens verkliga hjältar.
} 
Genom att berätta om ingusjiernas öde distanserar man sig från den sovjetiska (stalinistiska) historieskrivningen där de framställdes som landsförrädare. I stället lyfter man fram deras bidrag till segern och de oförrätter de utsatts för: "Medan ingusjiska soldater beskyddade fäderneslandet från fascisterna, skickades deras familjer med våld i väg från fädernehemmen” (Malik 2005). Genom att göra detta stärker man bilden av det sovjetiska folket som stod enat mot fascisterna. Man lyfter också fram kategorin ryssländare och framhåller segerdagen som en högtid för alla Rysslands folkgrupper.

Det är en mångfald av människoöden som möter en i berättelserna från kriget, men detta till trots så är veteranernas berättelser som de uttrycks i tidningarna märkligt samstämmiga. I en artikel om krigets barn i Komsomolskaja pravda uttrycks detta med ett fabricerat citat från alla krigets barn: "Hos var och en av oss finns vårt eget krigsöde, men vårt hjältedåd är gemensamt. Det är vår generations hjältedåd. Vi krigets barn - vars barndom tog slut 22 juni 1941" (Svetlitjnaja 2005). Även om detaljerna, varje berättelses enskildheter, varierar, berättar man i stort sett samma historia. Det är en historia om fosterlandskärlek, om lidande och uppoffringar, och om hjältedåd och uthållighet. De enskilda berättelserna formar ledigt in sig i vad som Barbara Törnquist-Plewa (2004) kallar Den stora berättelsen om kriget:

[Sovjetunionens invånare bjöd] ett enat och hårdnackat motstånd mot den fascistiske angriparen (...) Sovjetmedborgarna, drivna av de höga ideal som partiet förmedlade, var beredda att betala med sitt blod för försvaret av sitt kommunistiska fosterland och för att bringa frihet till de ockuperade folken i Europa (Törnquist-Plewa 2004: 325).

Veteranernas berättelser reflekterar den sovjetiska stora berättelsen om kriget och segern. Även om man på vissa sätt försöker distansera sig från denna, till exempel genom att diskutera tidigare tabuämnen, hotar detta inte, utan kanske snarare stärker, Den stora berättelsen om kriget. Orättvisa från överordnade stärker folkets hjältedåd, hemskheterna de fick utstå gör deras lidande och uppoffringar starkare, att rehabilitera folkgrupper som stämplats som förrädare visar på folkens enighet mot angriparen. 
Något som överhuvudtaget inte lyfts fram är dock de som inte levde upp till denna stora berättelse. Det finns inga exempel på någon som inte gjorde motstånd mot tyskarna. Inga ryska kollaboratörer omtalas, även om man skriver om baltiska sådana. Ämnen som skulle kunna hota Den stora berättelsen om kriget, som krigsförbrytelser av sovjetiska soldater, lyser nästan helt med sin frånvaro. Det finns nästan inga avvikande röster. Inget som visar på en annan tolkning av kriget och segern. Den röst som Dickinson menar splittrades efter Sovjetunionens fall verkar ha enats igen.

Amir Weiner (2001) diskuterar hjältemodets roll i den sovjetiska myten om kriget. Han menar att de som valde liv och säkerhet kontrasterades med de som valde risk och uppoffring. Passivitet likställdes med fientlig aktivitet. Både inom och utom partiet var, skriver Weiner, bristande hjältemod under kriget ett stigma som aldrig gick bort (Weiner 2001: 84, 160). Det patriotiska framhålls i många av veteranernas berättelser, man pratar om kärleken till fosterlandet (rodina) som då var Sovjetunionen. Visst finns det också de som var ideologiskt motiverade, det har framhållits att den så kallade frontgenerationen som växte upp under Sovjetunionens första år hade en stark ideologisk drivkraft (se t.ex. Weiner 2001, Krylova 2004b). Men det finns i artiklarna ingen motsättning mellan det patriotiska och det kommunistiska även om det främst är fosterlandskärleken som framhålls.

Det unisona, där mångfalden av röster fogar sig i en stor berättelse är besläktad med den process av mytifiering, ritualisering och formalisering som kan ses i dekorationer och övrigt firande av segerdagen. Veteranernas berättande av sina historier för tidningarna hänger samman med hur bilder av dem används som symboler på affischer och kort, samt med deras framträdanden, uniformsprydda och medaljbehängda, i parader, segertåg och skolor. Det är ritualiserade framträdanden, och berättelserna är i linje med dessa. Det är naturligtvis en lägre grad av formalisering, men även berättelserna ritualiseras. De blir till symboler, myter och kan betraktas på samma sätt utifrån Barthes modell. När myten ändrar betydelse, sker detta mer uttalat med berättelser från kriget. Berättelserna modifieras genom att ord kan ändras och episoder utelämnas eller läggs till. Som Dickinson visar, ändras berättelser efter kontext. Och omtolkningen sker på ett bokstavligt plan. Hur berättelserna framförs hänger samman med den generella myten om kriget. 


\section{Segerns roll idag}

Båda tidningarna publicerade artiklar som reflekterar kring segerns betydelse idag. Den 4 maj publicerade Arumenty i fakti artikeln "Vad återstår av segern?” I dess inledning konstaterar artikelförfattaren att detta är en "svår och bitter fråga" som landets veteraner idag ställer sig: För varje år minskar veteranerna i antal och om några år kommer den sista soldaten från segern dö; då kommer man bara känna till kriget från böcker, gamla filmer och fotografier (Kostikov 2005). Dagens tonåringar har inte ens egna minnen av Sovjetunionen, de attraheras inte av förfluten storhet. När segerdagen nu närmade sig skulle man inte glömma, framhåller artikelförfattaren, att det enade segrande folket nu hade delats i en mängd olika delar. Ett privatiserat land för oligarker och ett fattiggjort, rånat folk. Han skriver om allt man har förlorat och att "segern är den sista reserven för vårt hopp, samvete, minne, tålamod. Trons sista tillflyktsort" (Kostikov 2005).

Ett annat exempel är "Det har hänt något med vårt minne”, som Komsomolskaja pravda publicerade i slutet av april. Det är en lång reflekterande artikel kring kriget, veteranerna och dagsläget i landet. Artikeln tar utgångspunkt i författarens far- och morföräldrars krigsupplevelser, och hur han som barn vid 30-årsjubileet förundrades över hur man kunde bry sig om, ja ens minnas, något som hände för så länge sedan. Han skriver om frågorna som dykt upp efter Sovjetunionens fall: Var det värt det? Varför slogs vi? Han skräms av historielösheten där nazistiska symboler dyker upp i Ryssland i dag, och där unga hellre ser amerikanska krigsfilmer än ryska. Han skriver att folk överger minnet av kriget, men avslutar ändå med förhoppningen att den eviga lågan ska fortsätta brinna mot 70-årsjubileet och efter det (Sokolskij 2005). Myten om kriget hotas av historielöshet och glömska. Särskilt upprörande för många är den paradoxala förekomsten av nynazism i Ryssland. Men det finns också rädsla över vad som ska hända när veteranerna dör och det inte längre finns några levande minnen av kriget.

En infekterad fråga under våren 2005 var de krav på ursäkt och kompensation som hade framförts av flera tidigare sovjetrepubliker. Flera ledare i de forna delrepublikerna stannade hemma från jubileet i Moskva, och framförde att man inte ville fira vad man ansåg vara sovjetisk ockupation. De baltiska staterna, kanske främst Estland, stod i centrum i den här debatten. Som svar på beskyllningar om sovjetisk 
ockupation möter man i tidningarna ofta anklagelser om baltisk fascism, till exempel ägnas en stor del av en intervju med Estlands president i Argumenty i fakti 23 mars åt frågan om balter som slogs med nazisterna (Zotov 2005). Något av ett undantag $\mathrm{i}$ rapporteringen utgör en artikel i Komsomolskaja pravda som försöker se båda sidor av saken. I denna frågar sig journalisten: "Vad är det vi tycker minst om hos våra grannar: samtidens politiska realitet eller deras förhållande till kriget, annorlunda än vårt?” (Sapozjnikova 2005). Att relationen mellan Ryssland och de baltiska staterna inte varit den bästa bidrog säkert till att göra frågan om synen på kriget än mer problematisk. Frågan visar hur nära Sovjetunionen och krigsinsatserna hänger ihop. Att kalla sovjettiden för ockupation ifrågasätter segerns värde och tar ifrån veteranerna deras roll som befriare.

Ett tema som däremot inte får särskilt stor plats i rapporteringen är Förintelsen. Det är bara en artikel i mitt material som direkt berör Förintelsen, i ytterligare några artiklar nämns den i förbigående. Weiner menar att massmordet på judar aldrig förnekades $\mathrm{i}$ sovjetiska representationer av kriget, men att det förtegs (Weiner 2001: 290). Tumarkin menar att förtigandet av Förintelsen hänger samman med en vilja att vara högst i vad som kan kallas "lidandets hierarki”": Att erkänna och föra fram Förintelsen innebär att man fråntar det sovjetiska folket dess status som "supervictim, par excellence" på vilken man baserade mycket legitimitet (Tumarkin 1994: 50).

Ett annat hot mot minnet av kriget är sovjetiska soldater som betedde sig allt annat än hjältelikt - ett ämne som är flitigt förekommande i västerländsk historieskrivning, men som är i stort sett frånvarande i Ryssland. I en intervju med mannen som kallas perestrojkans arkitekt, Aleksandr Jakovlev (1923-2005), berörs ämnet dock. Jakovlev är veteran från stora fosterländska kriget och framställs som en man med auktoritet att kommentera samtid och historia. Frågan lyder: "På senare tid har det börjat skrivas och pratas om massvåldtäkter på tyska kvinnor av våra soldater, och om plundringar från våra styrkor. Förekom det?” Jakovlev svarar: "Naturligtvis (...). För plundring och ödeläggelse sköts våra soldater och officerare.” Sen skyndar man vidare till nästa fråga (Svartsevitj 2005). Sovjetiska krigsförbrytelser hotar Den stora berättelsen om kriget där hjältemodet är en central ingrediens. Det är ett tema som är nästan helt frånvarande i tidningarnas rapportering om kriget. När man nämner det, förnekas det oftast, och man hänvisar gärna till grymheter utförda av andra länder för att 
rättfärdiga de egna soldaternas beteende. Eller när det erkänns, som i exemplet ovan, betonas att de skyldiga straffades och man fördjupar sig inte vidare i ämnet.

Det finns i artiklarna en viss ambivalens i förhållandet till Sovjetunionen. Man erkänner brister och fel i det systemet, och försöker delvis distansera sig från den sovjetiska historieskrivningen. Samtidigt för man fram samma historia med mycket små ändringar. Synen på Sovjetunionen präglas också av nostalgi, det var landet man slogs för, det förlorade fosterlandet. Det finns en besvikelse på den nya tiden, och vad den fört med sig i form av ökade orättvisor och fattigdom.

\section{Avslutning}

Bilden av andra världskriget präglas av lidande, uppoffringar och stort hjältemod. Bara i benämningen stora fosterländska kriget istället för andra världskriget avslöjas ganska mycket. Segern framhålls som den sovjetiska segern, och Sovjetunionen och sovjetiska symbolen har en framskjuten roll i firandet. Den sovjetnostalgi man kan se i firandet, bör inte främst tolkas som en längtan efter kommunism eller det sovjetiska systemet. Symbolerna står inte främst för det ideologiska, utan det patriotiska. Segern framställs som länken till en forn storhet. Landet man slogs för finns inte längre, men man var efter segern medborgare i en supermakt. Storheten uttrycks också på ett mer abstrakt plan, då man hyllar de egenskaper som ledde det sovjetiska folket till seger.

Det flitiga användandet av ett fåtal symboler samverkar med firandets rituella drag till att renodla segerns budskap. Firandet av segerdagen betonar hjältedåd och triumf, och symboler och dekorationer lyfter tydligt fram dessa aspekter av kriget. Även det stora lidande som Sovjetunionens befolkning utsattes för ges stor plats i rapporteringen, där andra nationers lidande bara skymtar. De andra tolkningar av kriget som förts fram bland annat från Baltikum diskrediteras till största delen. Påståenden om att segern var början på en ny ofrihet förringar det sovjetiska folkets insatser, det antyder att de dog förgäves eller ännu värre, för fel sak. Sådant som direkt motsäger sovjetiskt hjältedåd, som krigsförbrytelser av röda armén, är i princip helt frånvarande från rapporteringen.

Segerdagen har nationellt enande funktioner. Fosterlandskärlek är ett centralt tema i veteranernas berättelser. Patriotismen framställs genomgående i icke-etniska termer. 
Segerdagen stärker enigheten inåt, det är en högtid som är gemensam för alla Rysslands (Sovjetunionens) folk. Det är en överetnisk högtid och det framhålls hur olika folkslag kämpade sida vid sida. Under själva segerdagen finns hos deltagarna i firandet en påtaglig känsla av gemenskap.

Kriget är en verklig historisk händelse, men har också flera drag av myt. Historien i denna mytiska tappning renodlas, där finns ingen plats för kaos och förvirring. Det finns många ord, uttryck och bilder som är fyllda av ett mytiskt budskap, vilket kan sägas vara renodlat och icke-resonerande.

Firandet 2005 liknar mer beskrivningarna av firandet under sovjettiden än beskrivningarna av firandet på 1990-talet. Det officiella firandet är nu i linje med det “inofficiella” firandet som ändå skedde under 1990-talet, där veteraner tågade och viftade med röda fanor. Försöken att inlemma segern i en "rysk tradition" som Jeltsin gjorde tycks vara helt övergivna. Det är nu inget tvivel om att det är Sovjetunionen som är segrarmakten. Det handlar inte längre om att bryta med det förflutna, utan det sovjetiska har inkorporerats i det post-sovjetiska Ryssland. Man tycks ha kommit ett helt varv i synen på Sovjetunionen. I segerdagen finns både nostalgi och framåtanda. Med utgångspunkt i det ärofulla förflutna riktar man blicken mot framtiden.

\section{Litteratur}

Anderson, Benedict (1991) Imagined Communities: Reflections on the Origin and Spread of Nationalism. London: Verso.

Barthes, Roland (1970) Mytologier. Stockholm: Bo Cavefors bokförlag.

Borén, Thomas (2005) Meeting-places of Transformation: Urban Identity, Spatial Representations and Local Politics in St Petersburg, Russia. Stockholm: Stockholms universitet.

Crowley, David \& Susan E. Reid (2002) Socialist Spaces: Sites of Everyday Life in the Eastern Bloc. Oxford/New York, NY: Berg. 
Dickinson, Jennifer (1995) Building the Blockade: New Truths in Survival Narratives from Leningrad. Anthropology of East Europe Review 13 (2)

(http://condor.depaul.edu/ rrotenbe/aeer/aeer13_2/Dickenson.html).

Eriksen, Thomas Hylland (1996) Kampen om fortiden: Et essay om myter, identitet og politikk. Oslo: Aschehoug.

Harrison, Mark (2003) Counting Soviet Deaths in the Great Patriotic War: Comment. Europe-Asia Studies 55 (6): 939-44.

Kapferer, Bruce (1988) Legends of People Myths of State: Violence, Intolerance, and Political Culture in Sri Lanka and Australia. Washington, D.C.: Smithsonian Institution Press.

Kostikov, Vjatjeslav (2005) Tjto ostalos ot pobedy? Argumenty i fakty 4 maj.

Krikunov, Konstantin (2005) Ingusjskie soldaty Leningrada. Argumenty i fakty 16 mars.

Krylova, Anna (2004a) "Dancing on the Graves of the Dead: Building a World War II Memorial in Post-Soviet Russia” i Daniel J. Walkowitz \& Lisa Maya Knauer (red.) Memory and the Impact of Political Transformation in Public Space. Durham, NC: Duke University Press.

Krylova, Anna (2004b) Stalinist Identity from the Viewpoint of Gender: Rearing a Generation of Professionally Violent Women-Fighters in 1930s Stalinist Russia. Gender \& History 16 (3): 626-53.

Lévi-Strauss, Claude (1987) Det vilda tänkandet. Lund: Arkiv moderna klassiker.

Malik, Jekaterina (2005) Pomnit o prosjlom, dumat o budusjtjem. Komsomolskaja pravda 22 februari.

Moore, Sally F. \& Barbara G. Myerhoff (1977) “Introduction: Secular Ritual - Forms and Meaning” i

Sally F. Moore \& Barbara G. Myerhoff (red.) Secular Ritual. Assen: Van Gorcum.

Peskov, Vasilij (2005) Ja s nimi govorili... Komsomolskaja pravda 2 februari.

Ries, Nancy (1997) Russian Talk. Culture and Conversation during Perestroika. Ithaca, NY: Cornell University Press.

Sapozjnikova, Galina (2005) Potjemu pribalty nosjat esesovskie kresty. Komsomolskaja pravda 17 mars.

Sokolskij, Aleksej (2005) Tjto-to s pamjatju u nas stalo. Komsomolskaja pravda 24 april. 
Svartsevitj, Vladimir (2005) Vojnu nado otjistit ot vranja. Argumenty i fakty 23 februari.

Svetlitjnaja, Anna (2005) Deti Vojny. Komsomolskaja pravda 8 april.

Tumarkin, Nina (1994) The Living and the Dead: The Rise and Fall of the Cult of World War II in Russia. New York, NY: Basic Books.

Turner, Victor (1995) The Ritual Process: Structure and Anti-Structure. New York, NY: Aldine de Gruyter.

Törnquist-Plewa, Barbara (2004) “Enade vi stod”? Postsovjetiska berättelser om andra världskriget i Vitryssland. Nordisk Østforum 18 (3): 325-44.

Weiner, Amir (2001) Making Sense of War: The Second World War and the Fate of the Bolshevik Revolution. Princeton, NJ: Princeton University Press.

Zotov, Georgij (2005) Prezident Estonii Arnold Rjutel: Razve my voschvaljajem natsizm? Argumenty $i$ fakty 23 mars.

\section{Johanna Lärkner}

Master i socialantropologi från Universitetet i Oslo 

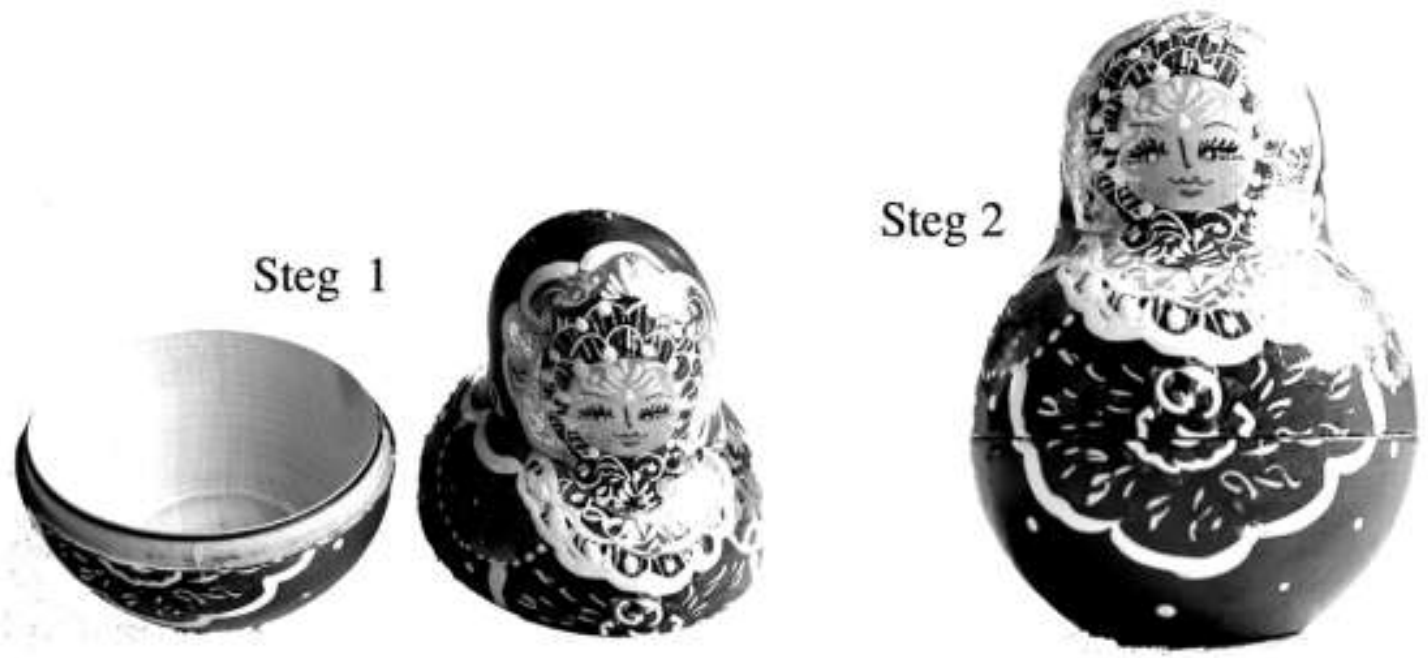

Betecknande och betecknade kombineras till tecken.
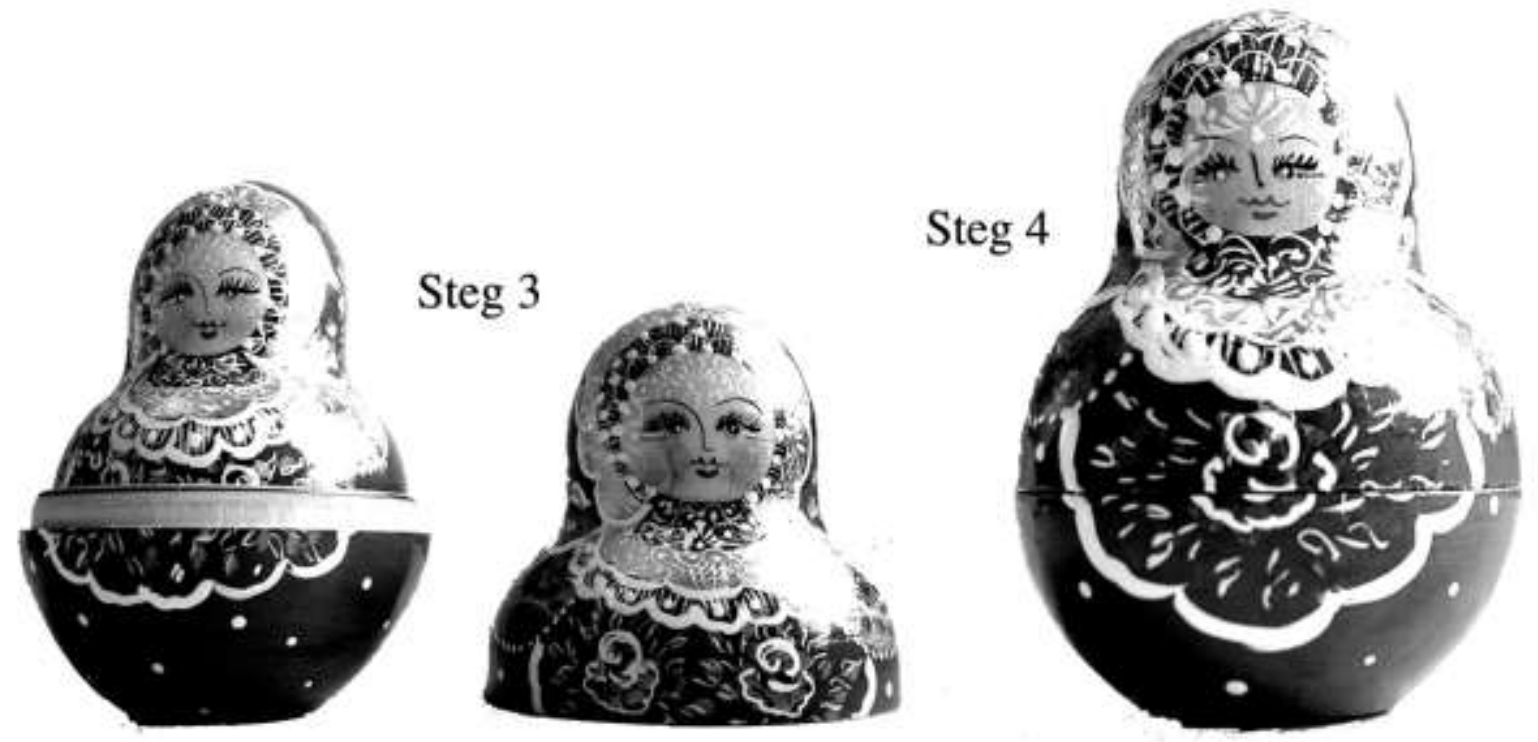

Av tecknet $i$ steg två bildads nytt betecknande som kombineras med nytt betecknade till ett nytt tecken. 